\title{
O Instituto de Fomento e Economia Agrícola do Estado do Rio de Janeiro (1926-1931) e a política fluminense de defesa do café na segunda metade da década de 1920: contribuição ao estudo de sua gênese e funcionamento
}

\author{
Almir Pita Freitas Filho ${ }^{1}$
}

RESUMO

Apresentamos neste artigo a origem e atuação do Instituto de Fomento e Economia Agrícola do Estado do Rio de Janeiro (IFEA-RJ) face à agricultura fluminense, em especial a cafeicultura, na segunda metade da década de 1920. Criado em agosto de 1926 pelo chefe do Executivo local, Feliciano Pires de Abreu Sodré, para concretizar a política de defesa permanente do café, sob a responsabilidade dos governos estaduais, o IFEA-RJ buscou também ampliar sua ação promotora, incluindo outros produtos e procedimentos organizacionais em relação ao setor agrário local. Essa particularidade, aliada à escassez de estudos sobre a instituição são as principais justificativas para essa investigação.

Palavras-chave: Cafeicultura fluminense; Instituto de Fomento e Economia Agrícola; Década de 1920

\begin{abstract}
This article examines the origin and role of the Institute of Development and Agricultural Economics of the State of Rio de Janeiro (RJ-IFEA) face the agrarian sector, particularly coffee, in the second half of the 1920s. Created in August 1926 by the head of the local executive, Feliciano Pires de Abreu Sodré, to implement the policy of permanent defense coffee, under the responsibility of state governments, the IFEA-RJ also sought to broaden its activities providers, including other products and procedures organization in relation to local agrarian sector. This peculiarity, together with the scarcity of studies on the institution are the main reasons for this investigation.
\end{abstract}

Keywords: Institute of Development and Agricultural Economics; coffee policy's of permanent defense; The State of Rio de Janeiro State on coffee economics; 1920 decade.

\footnotetext{
${ }^{1}$ Doutor em História Econômica pela Universidade de São Paulo (USP). Professor Associado - Universidade Federal do Rio de Janeiro, Instituto de Economia (UFRJ/IE). almir@ie.ufrj.br
} 


\section{Introdução}

Apresentamos neste trabalho ${ }^{2}$ a origem e atuação do Instituto de Fomento e Economia Agrícola do Estado do Rio de Janeiro (IFEA-RJ) face à agricultura fluminense, em especial a cafeicultura, na segunda metade da década de 1920. Criado em agosto de 1926 pelo chefe do Executivo local, Feliciano Pires de Abreu Sodré, a instituição tinha, entre seus objetivos, concretizar a política de defesa permanente do café, sob a responsabilidade dos governos estaduais. Contemporâneo de organizações congêneres criadas em outros estados, a exemplo do Instituto Paulista de Defesa Permanente do Café, do Instituto Mineiro de Defesa do Café e do Serviço de Defesa do Café do Estado do Espírito Santo, o IFEA-RJ singularizou-se por ter bases mais amplas de atuação, englobando outros produtos e procedimentos voltados para organizar a agricultura local, além do café. Essa particularidade, aliada à escassez de análises sobre a instituição são as principais justificativas para esse estudo.

A base documental principal deste artigo é constituída pelos Relatórios do IFEA-RJ dos anos de 1926 a 1929, seus estatutos e regulamentos, além de publicações patrocinadas pelo órgão. Complementam essa documentação as Mensagens Presidenciais à Assembleia Legislativa do Estado do Rio de Janeiro, de 1926 a 1930; a legislação, estadual e federal, referente à defesa permanente do café; publicações oficiais sobre o café no Brasil na década de 1920, assim como estudos sobre a história política e econômica do Brasil e do Rio de Janeiro no período.

O pressuposto teórico do estudo considera que o Estado brasileiro desempenhou uma ação intervencionista significativa na vida econômica do período em questão. Mesmo tratando-se de um Estado que procurava se ajustar ao modelo liberal, suas funções foram sendo pragmaticamente ampliadas, diante de condições econômicas e sociais específicas. Tais funções implicaram, entre outros, a criação de uma legislação e de aparelhos institucionais regulatórios que imprimiram uma particularidade às ideias e práticas econômicas adotadas, aproximando-as cada vez mais de um padrão intervencionista.

De acordo com Topik (1987), a participação do estado na vida econômica do Brasil, entre 1889 e 1930, pode ser explicada mais pelos fatores de ordem econômica e social e

\footnotetext{
${ }^{2}$ Uma versão anterior deste texto encontra-se publicada nos Anais do XXVI Simpósio Nacional da ANPUH. São Paulo: ANPUH-SP, 2011 (http://www.snh2011.anpuh.org/site/anaiscomplementares). O artigo é resultado do estágio de pós-doutorado desenvolvido junto ao programa de pós-graduação em História da Universidade Federal Fluminense, realizado no segundo semestre de 2012. Nesses termos, agradeço ao Instituto de Economia pela liberação da carga didática no período assinalado; ao Prof. Dr. Théo Lobarinhas Piñhero, supervisor do estágio; e ao Grupo Polis de História Econômica, pelas críticas recebidas por ocasião da apresentação da primeira versão deste trabalho. Os erros remanescentes permanecem sob minha inteira responsabilidade.
} 
menos pelas ideias ou intenção dos agentes econômicos. $\mathrm{O}$ autor argumenta que:

(...) foram conflitos de interesses entre vários segmentos da classe dominante e entre investidores estrangeiros que levaram a uma gradativa participação do Estado na economia, muito maior que inicialmente desejada pelos participantes. A estrutura da sua economia e da sua sociedade, e não as intenções dos atores, podem explicar a crescente presença do Estado brasileiro na sua economia. Um exame do processo que levou o Estado a envolver-se mais e mais nas finanças, no comércio cafeeiro, nas ferrovias e na indústria, mostra as estruturas paradoxais responsáveis pela participação do Estado na economia exportadora do Brasil. (Topik, 1987, p. 37; grifos nossos)

São, portanto, os conflitos de interesses, internos e externos, que ajudam a entender o porquê de, durante a Primeira República, terem convivido, lado a lado, propostas e práticas de política econômica identificadas ora com o liberalismo ora com o intervencionismo. Os ideais econômicos representados por Rui Barbosa e Joaquim Murtinho estiveram presentes ao longo dos anos em questão, estabelecendo os parâmetros que nortearam a elaboração das principais políticas econômicas republicanas, entre as quais a defesa permanente do café na década de $1920 .^{3}$

Segue a esta Introdução uma breve contextualização econômica e política da conjuntura histórica que deu origem ao IFEA. Em sequência, tratamos da criação, objetivos e organização da instituição, destacando elementos de sua dinâmica e formas de atuação na implantação da política de defesa do café no Estado do Rio de Janeiro. Por fim, algumas considerações que procuram articular as premissas teóricas que embasam a análise da instituição e sua prática em relação à cafeicultura fluminense, em um momento de crise e reestruturação do setor e da economia brasileira em seu conjunto.

\section{Defesa permanente do café e conflitos interoligárquicos: o contexto da criação do IFEA-RJ}

Entre nós, a produção como o comércio do café sempre estiveram à mercê de sua própria sorte. Os governos só intervinham com leis de emergência, quando os males da lavoura ameaçavam ocasionais desastres financeiros para o país. Passada a crise, voltava-se à situação de absoluto empirismo econômico e financeiro nos negócios do café (...).

(IFEA. O café fluminense e o Instituto de Fomento e Economia Agrícola. 1926-7:6)

Ações mais coordenadas voltadas para defesa do setor cafeeiro podem ser datadas de

\footnotetext{
${ }^{3}$ Ministros da Fazenda responsáveis pela adoção de orientações distintas de política econômica na primeira década republicana: Rui Barbosa (1889-1891) e Joaquim Murtinho (1898-1902).
} 
1906, por ocasião do chamado "Convênio de Taubaté". Diante de uma oferta excessiva do produto, representantes dos três principais estados cafeeiros tentaram envolver o governo federal em uma operação destinada, basicamente, a evitar uma queda acentuada nos preços do mesmo. ${ }^{4}$

Em três ocasiões, 1906, 1917 e 1921, através da compra e armazenamento temporário de sacas excedentes de café, os governos estadual e federal lograram sustentar o preço externo do produto. As intervenções valorizadoras foram financiadas por empréstimos externos, internos ou pela conjugação de ambos. O êxito das políticas de valorização pode ser avaliado pelos resultados alcançados, tais como: contenção e até mesmo elevação dos preços do café; venda dos estoques excedentes retirados do mercado; liquidação antecipada dos empréstimos externos obtidos para compra do café em excesso; lucros obtidos pelos participantes das operações. Segundo Delfim Neto (1979:78), a rápida intervenção governamental na terceira valorização era resultante tanto dos bons lucros das operações anteriores quanto da aceitação do argumento de que a defesa dos preços do café era uma questão nacional. Fortalecia-se, desse modo, a posição dos defensores de uma política de valorização permanente, e não mais esporádica, para o café. Em mensagem enviada à Câmara dos Deputados em 17 de outubro de 1921 (Vidal, 1935:30), o então presidente Epitácio Pessoa reiterava a necessidade de uma ação defensiva mais duradoura: "Diante do papel preponderante que o café representa hoje na economia nacional, a lição amarga e eloquente dos fatos tornou iniludível a necessidade de se organizar quanto antes a defesa permanente desse produto (...)."

Em 1922, através do decreto federal no 4548, de 19 de junho, Epitácio Pessoa deu um passo importante para uma prática mais sistematizada em defesa do produto. Pelo artigo $6^{\circ}$ era criado o Instituto de Defesa Permanente do Café, com sede na capital federal. O novo órgão seria administrado por um conselho presidido pelos ministros da Fazenda, da Agricultura e mais cinco membros nomeados pelo presidente da República, "entre pessoas de notória competência em assuntos agrícolas, comerciais e bancários". 5

As medidas para defesa dos preços do café consistiam: na concessão de empréstimos aos cafeicultores; na compra e retirada provisória do produto do mercado, visando regularizar a oferta; além do financiamento da propaganda no exterior, destinada a aumentar o consumo do mesmo. Para viabilizar essas ações era criado um fundo para defesa no valor de 300 contos

\footnotetext{
${ }^{4}$ Existe uma vasta literatura sobre o tema, dentre a qual destacamos para este trabalho: Delfim Neto (1979); Furtado (1972); Holloway (1978); Perissinotto (1999); Taunay (1945); Topik (1987); Vidal (1935).

5 Decreto $\mathrm{n}^{\circ} 4548$, de 19 de junho de 1922. Ver texto completo em: http://www2.camara.gov.br/legin/fed/decret/1920-1929/decreto-4548-19-junho-1922-568457-publicacao-91779pl.html
} 
de réis, quantia essa oriunda dos lucros com as operações da defesa; contribuições dos Estados; operações de crédito internas ou externas, além da emissão de papel moeda (ver parágrafo $5^{\circ}$ ).

Em 1922 Arthur Bernardes foi eleito para um período do governo de quatro anos, marcado por problemas econômicos e inúmeras manifestações políticas. Reapareciam as dificuldades que, tradicionalmente, afetavam a economia republicana, tais como o desequilíbrio nas contas públicas, desvalorização cambial e a forte dependência em relação às exportações cafeeiras. O agravamento do quadro levou o governo a adotar medidas de política econômica cada vez mais baseadas nos princípios da ortodoxia liberal. ${ }^{6}$ A política de defesa do café ganhou novos contornos com o decreto federal n ${ }^{\circ} 4868$ de 7 de novembro de $1924,{ }^{7}$ pelo qual a União, além de assegurar o abastecimento de café no mercado interno, transferia para o Estado de São Paulo os armazéns construídos em função do decreto de 1922 para regularem o transporte do produto. A partir de então cessava a ação do governo federal na defesa do café, que passava à responsabilidade dos estados produtores.

A criação de órgãos públicos estaduais voltados para defesa permanente do café foi uma das práticas seguidas pelos principais estados produtores a partir de 1924. Em 19 de dezembro daquele ano, pela lei 2004, era criado o Instituto Paulista de Defesa Permanente do Café, transformado em 1926 no Instituto do Café do Estado de São Paulo (Taunay, 1941:203; Delfim Netto, 1979:88; Perissinotto, 1999:170). Outros estados cafeicultores, a exemplo de Minas Gerais, Espírito Santo e Rio de Janeiro, adotaram procedimentos que implicavam ações de mais longo prazo na defesa do café. ${ }^{8}$

O objetivo principal destas ações era a regularização da entrada do café nos principais portos de exportação do produto. Partia-se do pressuposto de que, as remessas simultâneas de milhares de sacas de café davam aos comerciantes uma dimensão da oferta real do produto, contribuindo para uma queda nos preços, além dos efeitos sobre o mercado cambial, cuja estabilização era outro propósito perseguido pelo governo federal. ${ }^{9}$ Buscava-se, portanto,

\footnotetext{
${ }^{6}$ Para uma síntese das políticas econômicas na década de 1920 ver: Fausto SARETTA. A política econômica na década de 1920. In: De LORENZO e COSTA (1997:217-233).

7 Decreto $\mathrm{n}^{\circ} 4868$, de 7 de novembro de 1924 . Ver texto completo em: http://www2.camara.gov.br/legin/fed/decret/1920-1929/decreto-4868-7-novembro-1924-566476-publicacao90040-pl.html

${ }^{8}$ O governo do Estado de Minas Gerais vinha empreendendo diversas ações em defesa do café e, em 22 de março de 1929, criou o Instituto Minero de Defesa do Café, com sede na capital do país. Ver: Andrada. Mensagem, 1929:123-4.

${ }^{9}$ Do Relatório de Sampaio Vidal (Rafael de Abreu), ministro da Fazenda no ano de 1923. "A defesa do café, portanto, em última análise, visa, exclusivamente, evitar males consideráveis para a economia brasileira, isto é, a desordem da especulação do café e do câmbio, que são dois elementos relevantes da vida nacional" (Relatório, Rio de Janeiro, Imprensa Nacional, 1925, p. XXI).
} 
estabelecer um controle artificial da oferta do produto, com reflexo nos preços de venda do café, agora de forma permanente. Essa necessidade podia ser explicada, de acordo com Perissinoto (1999: I; p. 166), na medida em que "a lógica da economia exportadora cafeeira criava dificuldades permanentes à sua própria estabilidade”. Tal lógica foi sintetizada por Furtado (1972:180) no trecho a seguir:

\begin{abstract}
Mantendo-se firmes os preços, era evidente que os lucros se mantinham elevados. E também era óbvio que os negócios do café continuariam atrativos para os capitais que nele se formavam. Em outras palavras, as inversões nesse setor se manteriam em nível elevado, pressionando cada vez mais sobre a oferta. Dessa forma, a redução artificial da oferta engendrava a expansão dessa mesma oferta e criava um problema maior par o futuro.
\end{abstract}

Na década de 1920 esse futuro parecia ter chegado e, com ele, a necessidade de uma política menos esporádica, que levasse em conta o interesse dos produtores de café face ao comércio de importação.

O governo de Epitácio Pessoa percebeu tal necessidade, elencando as maiores dificuldades que envolviam o setor cafeeiro e justificavam a proposta de uma ação defensiva mais duradoura (Vidal, 1935:29).

\footnotetext{
As causas que perturbam a oferta do café são principal e incontestavelmente, de uma parte, a desigualdade das colheitas, (...), e de outra parte a falta de aparelhamento bancário apropriado para custear o armazenamento ou retenção da mercadoria à espera de melhores preços. (...) Essa situação se agrava com a falta de organização do mercado produtor (...) em frente de dez ou doze casas compradoras, apercebidas de todos os recursos para a luta, e ligadas pelo interesse comum de comprar a baixo preço.
}

A esse quadro podemos acrescentar as particularidades econômicas e políticas dos Estados produtores, em especial do Rio de Janeiro.

\title{
2. O café no Estado do Rio de Janeiro na década de 1920 e a criação do IFEA-RJ
}

Mais conhecida na historiografia por ser uma atividade em declínio desde o último quartel do século XIX, agravado pelo fim do regime de trabalho escravo, a cafeicultura no Estado do Rio de Janeiro vivenciava uma nova fase no início da década de 1920 ou, segundo Barros de Castro (1977), uma "sobrevida". De acordo com Ferreira (1994) e Mendonça (2008), esse novo momento era resultado de políticas adotadas por diferentes governos fluminenses ao longo da Primeira República, que teriam estimulado um processo de 
diversificação agrícola.

Por sua vez, na década de 1920, a retomada da cafeicultura no território fluminense também pode ser creditada aos efeitos das ações de valorização do produto que vinham sendo adotadas desde o início do século. Medidas essas que, de acordo com Barros de Castro (1977), beneficiavam tanto as áreas pioneiras e aquelas onde o café se encontrava em plena produção, quanto regiões em declínio, ou seja, sem vantagens comparativas.

Com base nos indicadores de produção e na localização da atividade cafeeira no território fluminense na década de 1920, é possível, grosso modo, identificar essas áreas, cuja situação agrária pode ser atribuída ao caráter "itinerante" do cafeeiro.

Ao longo da Primeira República, o Estado do Rio de Janeiro encontrava-se subdividido administrativamente em 48 municípios que, no início da década de 1930, formavam quatro regiões produtoras: Zona Serrana do Vale Sul do Paraíba; Zona Serrana do Centro; Zona Norte Fluminense ou do Vale Norte do Paraíba e Zona Litorânea ou da Baixada (Rangel, 1935:161-7; Melo, 1993:85). Ver Figura 1 em seguida:

Figura 1: Áreas cafeeiras do Estado do Rio de Janeiro na década de 1920

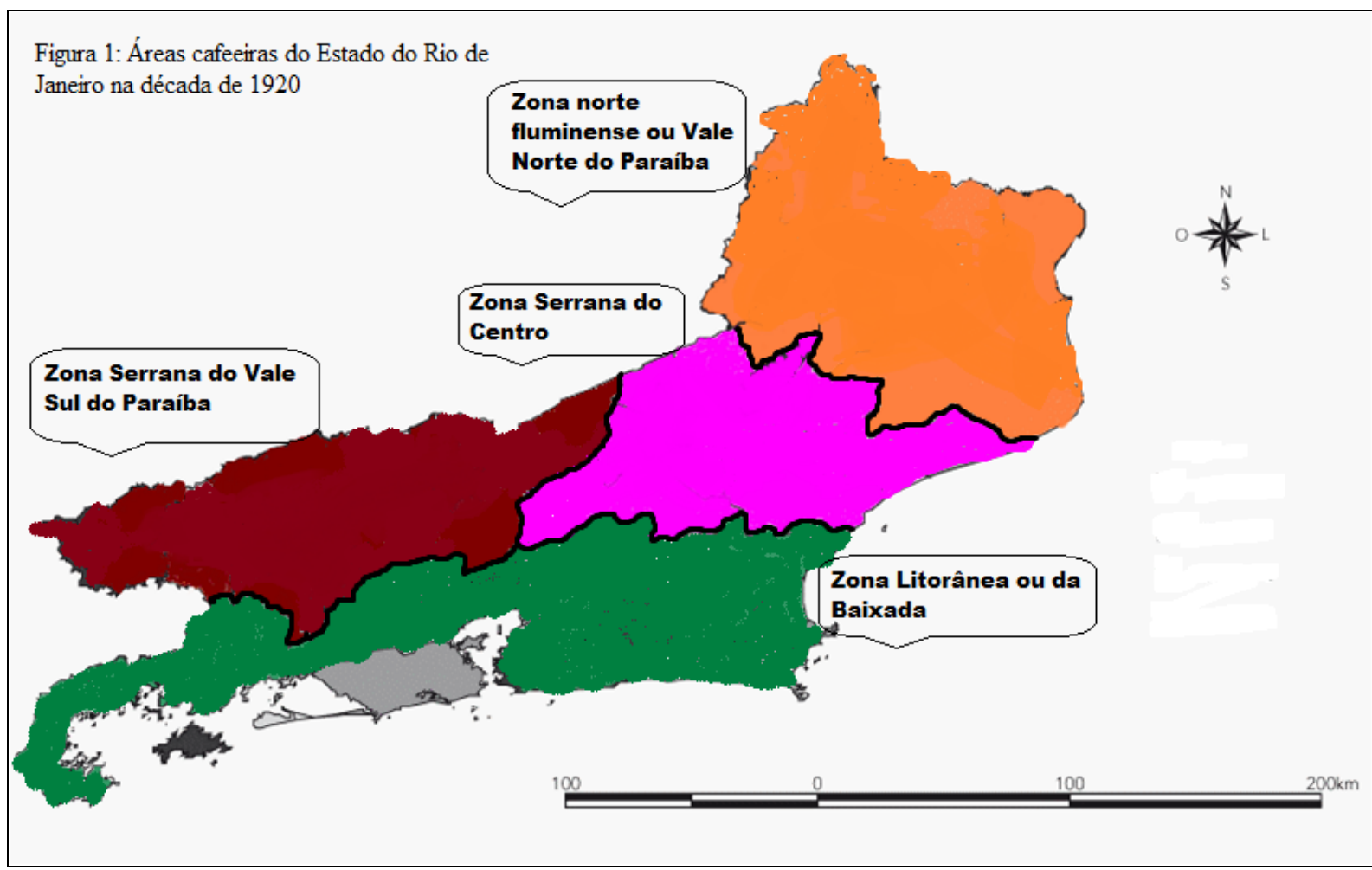

Fonte: Elaboração própria com base em: a) Ministério da Agricultura, Indústria e Comércio. Diretoria do Serviço de Estatística. Divisão administrativa em 1911 da República dos Estados Unidos do Brasil. Rio de Janeiro: Tip. anexa da Diretoria do Serviço de Estatística, 1911, p. 207-17; b) CIDE. Estado do Rio de Janeiro. Divisão Político-administrativa. 1998; c) IBGE. IBGE cidades@ - Rio de Janeiro. http://www.ibge.gov.br/cidadesat/index.php. Acesso em 07/03/2013; d) MELO, Hildete P. Op. Cit., p. 93, 100114. 
Seguindo essa divisão e com base nos dados da produção e exportação de café do Estado, é possível constatar que, no início da década de 1920, a principal área da cafeicultura fluminense havia se deslocado da Zona Serrana do Vale Sul do Paraíba para as zonas Norte Fluminense e Serrano do Centro. Nessas duas áreas se encontravam os municípios maiores produtores de café, a exemplo de Campos, Macaé, Bom Jardim, Santo Antônio de Pádua e Itaperuna, denominada “a metrópole da produção cafeeira” (Mello, 1934:419).

A sobrevida da lavoura cafeeira resultante desse deslocamento e sua importância para a economia fluminense foi reconhecida por Joaquim de Mello em 1927, quando da realização do Bicentenário da Introdução do Café no Brasil. ${ }^{10}$ Segundo Mello (1934:414-416; grifos nossos):

\begin{abstract}
Animados pelas medidas protetoras da velha indústria agrícola, como as sucessivas valorizações promovidas por São Paulo, as quais os governos fluminenses sempre se associavam, as classes produtoras voltaram a explorá-la, intensificando as plantações nos municípios do Nordeste e do Norte.

Quero dizer que, se o aniquilamento da lavoura cafeeira no sul golpeou fundo o Rio de Janeiro e feriu de morte os seus proprietários rurais, o tempo e a experiência se incumbiram de remediar esses males, fazendo-a ressurgir ao Norte do Estado, estimulando a produção de outras riquezas naturais, provocando as tentativas triunfantes das novas indústrias.
\end{abstract}

Os resultados desse novo cenário podem ser constatados, entre outros, nos indicadores da receita estadual em 1926. Naquela data, a contribuição do imposto sobre o café para a receita estadual, que em 1898 representou $70 \%$ do total, correspondeu a cerca de $30 \%$. As atividades que mais contribuíram para a arrecadação estadual, além o café, foram: açúcar; lenha; álcool; carvão vegetal, aguardente; aves e ovos; frutas; sal; e indústria manufatureira (Mello, 1934:414-415).

Diversificação da produção primária, deslocamento da lavoura cafeeira para o Norte do Estado e uma atividade manufatureira promissora nos municípios de Niterói, Petrópolis, Nova Friburgo, Valença, entre outros, eram as linhas gerais que definiam o quadro econômico fluminense em meados da década de 1920, à época da criação do IFEA-RJ.

\footnotetext{
${ }^{10}$ Em 15 de outubro de 1927, no dia dedicado ao Estado do Rio de Janeiro na Exposição do Bicentenário do Café no Brasil, o periódico O Jornal, do Rio de Janeiro, publicou um suplemento dedicado ao evento. Era um caderno com 12 secções de 16 páginas cada, totalizando 192 páginas com diversos pequenos ensaios, artigos e ilustrações sobre o tema, sob diferentes prismas. Dentre os inúmeros colaboradores, se destacavam autores de formações diversas, desde escritores de renome, políticos, comerciantes e homens públicos, a exemplo de: Sergio Buarque de Holanda; Oliveira Viana; Sampaio Correa; Ramalho Ortigão; Joaquim de Mello, Di Cavalcanti e Assis Châteaubriant. Todo esse valioso material foi reunido pelo Departamento Nacional do Café em 1934, publicado sob o título de O Café no segundo centenário de sua introdução no Brasil em dois volumes.
} 
Aos fatores de ordem econômica devemos ainda agregar as disputas entre frações da oligarquia local, que alteraram o cenário político fluminense na década de 1920. A intervenção federal no Estado, em janeiro de 1923, começou a modificar a situação política local, até então controlada pelos partidários de Nilo Peçanha. O afastamento do grupo nilista da direção política local abriu espaço para a ascensão de novas lideranças que controlarão o poder até o início da década de $1930 .{ }^{11}$ Nesses termos, a adesão ao programa de defesa do café configurava um importante instrumento no processo de legitimação do novo grupo no poder, iniciado com a eleição de Feliciano Sodré, em dezembro de 1924. De acordo com Ferreira (1989:278), a gestão de Sodré, no plano econômico, foi marcada pelo alinhamento às diretrizes dos grandes estados que se concretizavam na política de defesa do café.

\section{Notas sobre a história do IFEA/RJ}

O Instituto de Fomento e Economia Agrícola, (...), é um aparelho de assistência, organização e defesa dos produtores fluminenses. Como o principal desses é o café, base da receita estadual e da fortuna pública, é sobre ele que se exerce mais decisivamente a sua ação. (Mello, 1934:423)

A criação do IFEA/RJ, que foi antecedida por entendimentos e convênio entre os principais estados cafeicultores, se deu no bojo da política de valorização permanente do café instituída a partir de 1924, agora a cargo dos governos estaduais.

No Estado do Rio de Janeiro o Instituto foi idealizado pelo então presidente, Feliciano Pires de Abreu Sodré, em mensagem dirigida à Assembleia Legislativa a $1^{\circ}$ de agosto de 1926. Pela proposta, os objetivos do novo órgão eram bem amplos, destinados a: "promover a prosperidade da economia rural e o desenvolvimento da lavoura"; realizar empréstimos aos produtores sob condições de prazo e juros "razoáveis", garantidos pelo produto depositado em armazéns locais; organizar o serviço de informação, estatística e propaganda do café e outros produtos (IFEA/RJ, 1926-7:7).

O projeto de lei foi elaborado por uma comissão conjunta da Assembleia Legislativa e discutido na sessão de 9 de agosto de 1926. Uma das manifestações de apoio à iniciativa partiu do parlamentar Miranda Rosa que, em seu discurso, sublinhou o espírito de colaboração entre produtores e o Estado que marcava a proposta do Executivo. Segundo Rosa, (IFEA/RJ, 1926-7:17; grifos nossos):

\footnotetext{
${ }^{11}$ Para mais detalhes sobre a disputa interoligárquica fluminense no período da Primeira República, ver Ferreira (1989).
} 
A iniciativa do Sr. Presidente do Estado, concretizada no projeto criando o Instituto de Fomento Agrícola, corresponde inquestionavelmente ao pensamento hoje dominante entre os que procuram, para os problemas econômicos, soluções à luz das realidades palpáveis, sem o condicionamento sistemático aos preceitos escolásticos, incompatíveis com as complexas e vertiginosas condições da vida contemporânea.

Havia os que condenavam francamente a intervenção do Estado, colocandose no ponto de vista ortodoxo; havia os que encaravam o Estado, sobretudo nos países novos, como um verdadeiro tutor de todas as iniciativas.

Creio, porém, que é a primeira vez que se adota uma política em que não ocorre uma intervenção ostensiva e direta do Estado, desde que esta intervenção se processe através de um aparelho novo em que colaboram também decisivamente os órgãos das classes produtoras.

Outros pronunciamentos favoráveis ao projeto foram feitos, tendo, no entanto, algumas vozes discordantes, a exemplo do deputado Gambetta Perissé, ${ }^{12}$ que criticava o caráter estatal do novo órgão. Em sua concepção (IFEA/RJ, 1926-7: 27):

O aparelhamento administrativo que se quer criar neste momento virá entorpecer a marcha progressiva e espontânea, pela sua ligação direta com o Poder Executivo. (...) Essa dependência do poder virá trazer consequências gravíssimas, ônus pesadíssimos à terra fluminense, dada a urgente necessidade do emprego da verba a arrecadar em misteres outros a que ela não destina.

Praticamente sem uma oposição mais articulada, foi criado em 15 de agosto de 1926 o Instituto de Fomento e Economia Agrícola do Estado do Rio de Janeiro (IFEA/RJ), um órgão de utilidade pública com sede em Niterói, capital do Estado. Essa deliberação foi saudada pelo jornal $O$ Estado como o advento de uma nova política, protetora e defensiva das riquezas do Estado pelas autoridades governamentais, conforme o trecho a seguir (IFEA, 1926-7, 89):

\begin{abstract}
A Assembleia não poderia, pois, deixar de tomar com consideração a sugestão presidencial, concretizando-a em um projeto de lei que correspondesse, de fato, às aspirações das nossas classes produtoras, que lhes resguardassem os surtos das grandes, das imensas possibilidades econômicas do Estado do Rio, com o advento de uma política que se pode com propriedade chamar de estadismo e que significa a proteção e a defesa, dentro do Estado, de todos os elementos constitutivos de sua riqueza.
\end{abstract}

\title{
4. O IFEA/RJ: organização administrativa, funções e formas de atuação
}

O IFEA/RJ foi criado pela Lei $n^{\circ} 2014$ de 15 de agosto de 1926 e regulamentado pelo decreto $\mathrm{n}^{\circ} 2189$ de 21 de agosto de 1926. Sua administração era formada por uma Diretoria

\footnotetext{
${ }^{12}$ Mais detalhes sobre a filiação partidária do deputado Perissé e sua atuação na ALERJ em Ferreira (1989; 279281).
} 
composta por três membros: um presidente (que era o secretário de Finanças ou o de Agricultura e Obras Públicas, em caso de impedimento do primeiro) e dois diretores, um dos quais era o representante da lavoura, nomeados pelo presidente do Estado.

De acordo com o artigo $2^{\circ}$ da lei que o criou, uma das finalidades do Instituto era a de “promover a prosperidade da atividade agrícola em relação aos seus principais produtos". O novo órgão tinha, portanto, atribuições mais amplas do que as de seu congênere paulista. $\mathrm{O} 4^{\circ}$ parágrafo estabelecia que, além de promover a prosperidade da economia rural e o desenvolvimento da lavoura, era também função do IFEA/RJ: conceder empréstimos aos produtores mediante condições negociáveis de prazos e juros, dando como garantia o produto depositado nos armazéns gerais e reguladores (nos portos de Niterói e Angra dos Reis); organizar os serviços de informação, propaganda e estatística dos produtos relativos ao desenvolvimento da riqueza econômica do Estado; fazer a propaganda do regime imobiliário Torrens, criado pelo decreto federal de 31 de maio de $1890 ;{ }^{13}$ realizar um cadastro imobiliário, entre outras.

Pelo artigo $7^{\circ}$ o Instituto era encarregado da exploração dos portos de Niterói e Angra dos Reis. Estes serviriam de aparelhos reguladores de circulação econômica, comercial e agrícola. Os lucros líquidos anuais obtidos na exploração dos portos seriam divididos igualmente entre o Estado e o Instituto. É importante registrar que, de acordo com Ferreira (1989:278), na gestão de Feliciano Sodré foram retomadas as obras de construção do porto de Niterói, iniciadas em 1913 e interrompidas desde então.

As principais fontes de recursos do Instituto eram originadas das taxas criadas sobre os dois principais produtos de exportação do estado: um mil réis ouro por saca de café e 300 réis pela do açúcar. A introdução desses tributos implicou a suspensão da cobrança da sobretaxa de 3 francos ouro por saca de café estabelecida pelo decreto n. 1011 de 26 de dezembro de 1906. A nova tarifação também seria utilizada para pagamento dos serviços dos empréstimos, externos ou internos, que viessem a ser contraídos pelo Instituto.

Além das fontes de receita assinaladas, o Instituto dispunha ainda das rendas provenientes das exportações nos portos de Niterói e Angra dos Reis; dos lucros resultantes das operações financeiras realizadas; de taxas e emolumentos resultantes das operações

\footnotetext{
${ }^{13}$ O decreto federal n. 451B de 31 de maio de 1890 instituiu o Sistema Torrens de aquisição e transmissão da propriedade imobiliária, especialmente a territorial. A denominação presta tributo ao deputado australiano Robert Torrens, autor do projeto original de 1856. No Rio de Janeiro, o decreto foi adaptado à organização judiciária estadual pela lei n. 1223 de 26 de fevereiro de 1914, e regulamentada em 14 de julho de 1918 pelo decreto n. 1621. Para mais detalhes ver: Vianna \& Leite (1927); Motta (2005); Sanches (2008).
} 
relativas ao Registro Torrens. ${ }^{14}$

Em relação ao café, o artigo $8^{\circ}$ do Regulamento estabelecia as seguintes atribuições: levantar anualmente a estimativa da safra, por município e zonas tributárias de cada estrada de ferro; assentar com os representantes dos outros estados produtores a quantia de café que deveria ser enviada aos mercados exportadores, mensalmente ou em períodos determinados; facilitar aos produtores a remessa de seu café para os mercados que preferissem, proporcionalmente à produção de cada um; providenciar junto às estradas de ferro e companhias de transportes sobre a condução do produto com prontidão e na ordem rigorosa dos embarques; receber as reclamações dos interessados e providenciar sobre elas.

O transporte do café fluminense para os mercados de exportação seria regulado através da distribuição de quotas de embarques para as estações exportadores e com o auxílio dos armazéns reguladores a serem instalados nos portos de Niterói e Angra dos Reis (Decreto 2173 de 27 de abril de 1926).

As entradas de café no Rio de Janeiro seriam regularizadas, de modo a que não fossem superiores a seis mil (6000) sacas diárias, número esse que não deveria superar a base de 150.000 nos 25 dias do mês. Esse total havia sido acordado no convênio realizado com o Estado de São Paulo em 16 de abril de 1926, que antecedeu à criação do IFEA, e aprovado pelo Decreto ${ }^{\circ} 2173$ de dezembro do mesmo ano.

Regularizar o transporte e a remessa do café através da fixação de cotas, assim como realizar acordos com os demais estados produtores eram, portanto, os principais elementos da política estadual de defesa permanente do café na segunda metade da década de 1920. Essas medidas configuravam um padrão de intervenção do poder público na esfera da circulação do produto, fortalecendo as críticas dos opositores à tal modalidade de protecionismo, considerada ainda onerosa para os produtores. ${ }^{15}$

\section{A Direção inicial do IFEA}

O Regulamento do IFEA, em seu artigo $1^{\circ}$, estabelecia que o órgão fosse administrado por uma Diretoria constituída (art. 14) pelo secretário de Estado das Finanças (presidente) e

\footnotetext{
${ }^{14}$ Desde sua criação até o final de 1927 as principais fontes de receita do Instituto eram provenientes das taxas ouro sobre as exportações de café e açúcar. Ambas representaram 71,5\% do total arrecada da receita no período assinalado. Ver: IFEA (1926-7:378-382).

${ }^{15}$ Ações judiciais e recursos contra o Instituto por parte de produtores e casas comerciais de vários municípios foram algumas das formas de oposição às ações do Instituto (ver: IFEA, 1926-7:373-8). De acordo com Ferreira (1989:287-88), o movimento de oposição, que incluiu tentativas de criação de partidos políticos, teria se arrefecido a partir de 1927, com a adoção de medidas que atendiam aos interesses dos produtores.
} 
dois diretores nomeados pelo presidente do Estado, um dos quais eleitos pelos lavradores, de acordo com os artigos 16 a 18, além de um gerente de livre nomeação pelo chefe do executivo estadual. Em caso de impedimento do secretário das Finanças, a presidência do órgão era exercida pelo secretário de Agricultura e Obras Públicas. E ainda, de acordo com o art. 20 em caso de ser voto vencido nas resoluções da Diretoria, podia recorrer ao presidente do Estado para uma decisão final.

Anualmente, entre os meses de maio e junho, deveria ser feita a escolha do representante da lavoura, eleito pelo prazo de um ano pelos lavradores matriculados no Instituto, sendo permitida uma reeleição. Os eleitores enviavam uma cédula com a indicação do candidato para a Sociedade Fluminense de Agricultura e Indústrias Rurais. Junto a essas cédulas deveriam ser anexados os recibos de pagamento do Imposto Territorial relativos ao último exercício. A cada cédula se atribuiria um número de votos correspondentes às cotas de dois mil réis (2\$000), contidas no valor do imposto territorial pago pelo lavrador (ex.: 20\$000 pagos de imposto corresponderiam a 10 votos).

Como a criação do Instituto ocorreu no mês de agosto, a primeira eleição para representante da lavoura só foi realizada no ano seguinte, em 10 de junho de 1927. Até essa data, o cargo foi exercido interinamente por um representante nomeado pelo presidente do Estado, em comum acordo com a Sociedade Fluminense de Agricultura e Indústrias Rurais. A escolha recaiu sobre Eurico Teixeira Leite, ${ }^{16}$ vice-presidente em exercício da mesma sociedade e membro de tradicional família de cafeicultores do Município de Vassouras.

O primeiro presidente do Instituto foi o secretário de Estado das Finanças, Salvador Conceição, que permaneceu no cargo até julho de 1927. De julho a dezembro de 1927 o cargo foi ocupado por Arnaldo Tavares e, em seguida, por Antônio Joaquim de Mello. Para a nova Diretoria, constituída em 24 de agosto de 1926, foram nomeados Antônio Ilha Moreira e Eurico Teixeira Leite, sendo o cargo de gerente entregue a Francisco Correa de Figueiredo. Com a solicitação de exoneração de Ilha Moreira, em 28 de agosto foi nomeado Francisco José de Oliveira Vianna, "uma das figuras mais empolgantes do Brasil intelectual de nossos dias", segundo o jornal $O$ Estado (IFEA, 1926-7:104; 122).

A escolha de Oliveira Vianna, um dos teóricos de pensamento autoritário da década de 1930, para ocupar um cargo na Diretoria da nova Instituição fluminense foi registrada pelo $O$ Paiz em 3 de setembro de 1926. Na ocasião, o jornal considerou a pouca familiaridade de Vianna com assuntos econômicos, sublinhando ainda o caráter associativo entre Estado e

\footnotetext{
${ }^{16}$ Sobre as origens dessa família, ver: TAUNAY, Affonso d'E. Uma irmandade de grandes cafeicultores - os Teixeira Leite. O Jornal. Edição especial. 15 de outubro de 1927, Seç̧ão 7, p. 1-2.
} 
agricultores, presente na condução do IFEA (1926-7:105), conforme destaca o trecho a seguir:

\begin{abstract}
Ainda que não seja um espírito especializado nos estudos propriamente econômicos, o cintilante escritor está talhado para o posto entregue à sua alta capacidade, porque o Instituto de Fomento é destinado a exercer longa missão social educando as classes produtoras para a defesa eficaz de seus interesses, graças às associações da iniciativa particular com a ação dos poderes públicos. E ninguém pode guiá-los melhor nessa tarefa que o consagrado sociólogo, conhecedor profundo da nossa formação étnica, da nossa organização psicológica, das nossas tendências morais e dos nossos problemas culturais.
\end{abstract}

Oliveira Vianna permaneceu no cargo de diretor da Carteira Comercial e Financeira do IFEA, mesmo após a mudança do governo fluminense em dezembro de 1927, com a eleição de Manuel Mattos Duarte (1927-1930).

Na primeira reunião, realizada em 24 de agosto de 1926, além da elaboração dos Estatutos, ficou definido o local de sede da Instituição. Para tanto foi aceita a oferta do presidente da Caixa Auxiliadora e Beneficente dos Funcionários do Estado, Coronel José Mattoso Maia Forte, do imóvel situado à Rua Visconde de Sepetiba $n^{\circ} 337$, no centro de Niterói. O prédio foi entregue em 6 de setembro, tendo o Instituto iniciado suas atividades em 1 de outubro de 1926.

A dinâmica da Instituição, analisada através de suas ações reguladoras, foi marcada por alguns acontecimentos que ilustram as formas de atuação do poder público estadual em relação à economia no período. Um deles refere-se à eleição do diretor representante da lavoura, cuja escolha, através da participação direta dos lavradores como eleitores, se tornou um momento de tensão no interior do órgão. Nessa ocasião, afloravam as divergências e conflitos envolvendo representantes das classes agrícolas fluminenses e funcionários da burocracia estatal, assim como em relação aos órgãos públicos com funções reguladoras das atividades econômicas.

Como foi assinalado, a primeira eleição do diretor representante da lavoura só ocorreu em 1927. Nesse intervalo de tempo a direção do Instituto, através de sua gerência, procurou divulgar os procedimentos para a votação, expedindo circulares e enviando ofícios às prefeituras, coletorias e aos próprios lavradores, solicitando que se matriculassem (IFEA, 1926-7:159-162).

A imprensa foi outro veículo utilizado para divulgação da eleição do representante da lavoura. Neste sentido, destacou-se a colaboração de Oliveira Vianna, que, na edição de 29 de maio de 1927 do jornal $O$ Estado, assinou um artigo intitulado "Uma eleição de classe". Seu 
texto sublinhava a importância da escolha, feita através dos lavradores-eleitores, assim como da oportunidade para se realizar uma representação corporativa, antecipando no nível estadual o que viria a ser consagrado na Constituição Federal de 1934. Oliveira Vianna conclamava para a união dos agricultores, segmento visto ainda como disperso, desorganizado, como condição para partilhar do governo, garantindo através dessa "ação coletiva" o atendimento de suas demandas por parte dos governantes. Seguem alguns trechos do referido artigo (IFEA, 1926-7:162-3):

\begin{abstract}
Uma das causas principais do desinteresse que os governos mostram para com as classes que produzem está justamente em que estas classes não têm tradições de ação coletiva. Este traço é principalmente sensível na classe agrícola.

Esses movimentos corporativos devem partir do seio da própria classe agrícola, pela ação de seus próprios elementos, mas ardentes e combativos, mas capazes de persuasão e proselitismo; mas os governos também podem concorrer para isto, por meio de providências que provoquem e estimulem estes movimentos coletivos.

É o que vai acontecer certamente no Estado do Rio, com a providência que ali se estabeleceu para a eleição do representante da lavoura na diretoria do Instituto de Fomento e Economia Agrícola.
\end{abstract}

A apuração, realizada na sede social da Sociedade Fluminense de Agricultura e Indústrias Rurais em 10 de junho de 1927, reconduziu Eurico Teixeira Leite ao cargo de diretor representante da lavoura, eleito com um total de 113.545 votos. Os outros concorrentes foram: Francisco Badenes (100.939 votos); José Gonçalves Lessa Vieira (27.773 votos); Guido Hygino Rangel (840 votos) e Paulo Francisco Werneck (126 votos).

A eleição, porém, não transcorreu de forma tranquila, tendo sido questionada por um dos concorrentes, José G. Lessa Vieira. Uma das irregularidades apontadas foi a participação do chefe do Departamento de Fiscalização do Instituto, Francisco Bardenes, como candidato. Além disso, a maioria de seus votantes seria proveniente da Município de Campos, local onde seu irmão, Vicente Bardenes, exercia a função de Coletor das Rendas do Estado (IFEA, 1926/7:169).

A partir desse episódio, a direção do Instituto proibiu que funcionários participassem ou concorressem à eleição para o cargo de diretor representante da lavoura. Em 1929, por ocasião da alteração do Regulamento, servidores do órgão, de qualquer cargo ou função, foram considerados inelegíveis para referido cargo, exceto aquele já em exercício (Artigo $20^{\circ}$ do Regulamento do IFEA-RJ, 1929).

Na eleição seguinte, em 10 de junho de 1928, José Motta Vasconcellos foi o representante da lavoura eleito para direção do IFEA com 152.214 votos. Essa escolha 
também não transcorreu sem dificuldades. A comissão apuradora, alegando que Vasconcellos não era eleitor na cidade de Niterói e que, portanto, não poderia ser escolhido para o cargo, indicou o segundo colocado, Eurico T. Leite, que obtivera 91.700 votos. O presidente do Estado, Manuel de Mattos Duarte Silva, não aceitou tal argumentação e confirmou Motta Vasconcellos como diretor representante da lavoura (IFEA, 1928:4-20). Em seu despacho, o chefe do executivo fluminense assim se manifestou (Idem, 1928:20):

\begin{abstract}
Admitindo esse estranho modo de aplicar a lei, a vasta classe dos agricultores do Estado do Rio haveria de escolher sempre o seu representante obrigatoriamente dentro do eleitorado de Niterói. Na esquisita eleição, que assim se realizasse, a lavoura de todos os municípios do Estado entraria com o eleitorado, mas apenas um município daria os candidatos. (...) Do que assim fica fundamentalmente dito resulta que, na realidade o candidato mais votado, Dr. Jose Motta Vasconcellos, não é inelegível pelo fato de não ser eleitor na Capital do Estado e que lhe cabe, pois, nos termos explícitos da lei, o cargo de diretor do Fomento, representante da lavoura do Estado, eleito por maioria absoluta de sufrágios, na forma do Regulamento.
\end{abstract}

Uma melhor compreensão desses episódios deverá, sem dúvida, levar em conta a disputa entre segmentos da oligarquia fluminense por uma melhor posição no interior do aparelho estatal, em um contexto de crise do sistema político representativo da Primeira República ao final da década de 1920. Representantes de regiões agrícolas outrora florescentes eram levados à disputa e divisão do espaço político-institucional com grupos oriundos de áreas recém-incorporadas ao cenário produtivo, cada vez mais diversificado e marcado também pelos interesses de uma burocracia estatal em gestação.

\title{
6. O IFEA/RJ e a política de defesa do café no Rio de Janeiro
}

Mas o maior trabalho do Instituto, o que lhe tem absorvido o melhor de seu tempo, de suas atenções e cuidados e, como sabeis, o maior problema da atualidade nacional: a regulamentação dos transportes do café e da defesa de sua preço nos mercados de exportação. (IFEA, 1926-7:194-5)

Em relação ao café, as atribuições do IFEA eram estabelecidas pelo artigo $7^{\circ}$ de seus Estatutos e $8^{\circ}$ do Regulamento de 1926. Cabia ao Instituto estimar anualmente a safra da produção cafeeira fluminense, por municípios e zonas tributárias de cada estrada de ferro. $\mathrm{O}$ órgão deveria ainda definir, junto aos representantes dos demais estados produtores, a quantidade de café a ser encaminhada para exportação, mensalmente ou em períodos determinados. Facilitar a remessa do café para os mercados de preferência dos produtores, de acordo com a produção de cada um, junto às estradas de ferro e companhias de transportes, 
completava as funções operacionais da instituição.

A regularização do transporte do café era o cerne da política de defesa permanente. Para sua efetivação no território fluminense, o IFEA adotou a distribuição de cotas de embarque junto às estações exportadoras, aliada à instalação de armazéns reguladores, nos portos de Niterói e Angra dos Reis, conforme previa o Decreto n $^{\circ} 2173$ de 27 de abril de 1926. Também foi mantida a média diária de entrada de seis mil sacas de café no porto do Rio de Janeiro, em conformidade com o convênio celebrado com o Estado de São Paulo em 16 de abril e aprovado também pelo referido decreto.

Para atender à cota mensal estabelecida, inicialmente o Instituto fixou uma quantidade mensal de sacas que cada produtor poderia exportar. A remessa seria feita mediante a apresentação de guias do Instituto ao agente da estação de embarque de preferência do produtor, abolindo a prática anterior de guias distribuídas pelos próprios agentes. A fixação das cotas era condicionada à estimativa da safra de cada lavrador, dividida por doze, indicando seu limite mensal de exportação. A direção do órgão reconhecia que esse plano, embora elogiado por segmentos da cadeia comercial do café e por lavradores de maior produção, era rejeitado pelos produtores que colhiam menos de 150 sacas de café (IFEA, 1926-7:291).

Outro encargo do Instituto era o armazenamento de parte da produção em depósitos, os armazéns gerais ou reguladores, que controlavam a entrada do café no mercado exportador e, em consequência, os preços. Eram considerados como verdadeira "válvula de segurança", "que se comprime para impedir que entre no mercado quantidade superior à necessária, ou se distende para liberar o que haja armazenado, quando assim o exijam os interesses da defesa comercial do café" (IFEA, 1926-7:287).

Inicialmente considerados dispensáveis, os armazéns logo se tornaram peças essenciais da política de defesa permanente do café, na medida em que as cotas atribuídas às estações começaram a não atender às necessidades de circulação do produto, face à superprodução. As consequências desse quadro, negativas especialmente para os cafeicultores, foram assim resumidas pela direção do IFEA (1926-7:287, grifos nossos):

Os armazéns das estações, como os das casas comerciais, e até salas e quartos de casas particulares, davam a toda gente a dolorosa impressão de formidável massa de riqueza inteiramente paralisada. O lavrador, ávido de recursos para prosseguir ou terminar a colheita não os podia obter porque nenhuma providência de ordem financeira se lhes oferecia. O único expediente de que a maior parte dos produtores se valeram foi deixarem-se 
explorar pela ganância insaciável dos especuladores, que lhes comprava o café a preços reduzidíssimos para se locupletarem, depois, com os preços altos que a "defesa" vinha conseguindo fixar no mercado do Rio de Janeiro.

Em abril de 1927 a direção do IFEA deliberou sobre a criação de dois armazéns reguladores, um em Niterói e outro na cidade do Rio de Janeiro, destinados a auxiliarem na regulação das entradas do café fluminense no mercado da capital do país. Esses depósitos, além do controle das entradas diárias do produto, deveriam ser adaptados a fim de permitir que, futuramente, o café ali armazenado fosse dado com garantia para empréstimos a seus produtores (IFEA, 1926-7:137; 196-7).

O armazém regulador de Niterói, instalado em um imóvel da Sociedade Anônima Companhia Usinas Nacionais, que teve parte do prédio cedida para uso do estado, tinha capacidade para armazenar cerca de cem mil sacas de café. Já no Rio de Janeiro, o Instituto deliberou pela contratação de terceiros para o serviço de armazenamento do café fluminense, sendo seu primeiro armazém regulador instalado em 1 de junho de 1927. Entretanto, a partir de setembro de 1927, diante da necessidade de ampliação dos depósitos para o café que permanecia retido no interior do Estado, o IFEA passou a dispor de mais 10 armazéns autorizados (IFEA, 1926-7:319-337; 348-9).

O movimento de entrada e saída de sacas de café nos depósitos do IFEA entre julho de 1927 e março de 1928 aparece no Quadro 1 a seguir. Pelos dados apresentados conclui-se que, na safra de 1927-28, restaram cerca de 30\% do total de sacas de café que deram entrada nos armazéns reguladores da produção fluminense a cargo do Instituto.

Quadro 1. Movimento dos armazéns reguladores do café fluminense na safra de 1927-28 (Sacas de café)

\begin{tabular}{|c|c|c|c|c|}
\hline ANO & ORIGEM & ENTRADAS & SAÍDAS & RESTANTE \\
\hline \multirow[t]{3}{*}{1927 (Jul. a Dez.) } & RJ & 568.052 & 376.482 & \\
\hline & Niterói & 60.372 & 59.817 & \\
\hline & Total & 628.424 & 436.299 & 192.125 \\
\hline \multirow[t]{3}{*}{1928 (Jan. a Mar.) } & RJ & 198.996 & 145.157 & \\
\hline & Niterói & 25 & 351 & \\
\hline & Total & 199.021 & 145.508 & 245.638 \\
\hline $1927-1928$ & RJ & 767.048 & 521.639 & \\
\hline \multirow[t]{2}{*}{ (Total dos 9 meses) } & Niterói & 60.397 & 60.168 & \\
\hline & TOTAL & $\begin{array}{r}827.445 \\
(100,0 \%)\end{array}$ & $\begin{array}{l}\mathbf{5 8 1 . 8 0 7} \\
(\mathbf{7 0 , 3 \%})\end{array}$ & $\begin{array}{r}245.638 \\
(29,7 \%)\end{array}$ \\
\hline
\end{tabular}

Fonte: Elaboração própria a partir de dados obtidos em: IFEA-RJ. Relatório 1926-7, p. 347. 
A ação defensiva da cafeicultura fluminense deparou-se com alguns problemas operacionais que, no decorrer de sua aplicação cotidiana, podiam alterar os limites fixados nos acordos com os outros estados produtores. Um desses problemas era a divergência entre os dados estimados da produção pela Inspetoria de Rendas e os fornecidos por alguns lavradores e fiscais, base para o cálculo das cotas de embarque do café nas estações.

Outra dificuldade era a relutância da administração de algumas ferrovias em se adaptar às novas regras de transporte do café. A Central do Brasil e a Oeste de Minas, por exemplo, alegavam conflito de competência entre governos federal e estadual, criando um impasse para o transporte do café segundo as cotas fixadas. ${ }^{17}$

A fiscalização para cobrança do imposto de circulação entre os estados era outro impasse na regularização do transporte de café. Fiscais mineiros entendiam que toda café procedente do Rio de Janeiro que se encontrasse em território do estado aguardando embarque, ou por efeito da redução das cotas ou pela falta de vagões transportadores, estava sujeito ao pagamento de tributos. O impasse foi solucionado com um "aditamento" ao convênio fiscal firmado em 1923 entre os dois estados, declarando livres os embarques de café nas estações situadas na zona de fronteira com Minas Gerais (IFEA, 1926-7:275-6).

Por fim, cabe mencionar a campanha movida contra o sistema de cotas do café por parte de vários segmentos da cadeia comercial do produto. A direção do IFEA arrolou, dentre esses críticos, os compradores de café, privados dos favores dos agentes de estações; intermediário e açambarcadores, além de políticos, críticos tradicionais da ação do novo governo. Apesar desses obstáculos, a instituição teria realizado o primeiro cadastro da lavoura cafeeira do Estado, criando fichas nominais dos produtores, com informações sobre municípios, distritos, estações de embarque, números de pés de café, além de endereço postal e telegráfico. Entre setembro de 1926 e abril de 1927, o Instituto registrou 8628 propriedades cafeeiras, no valor de 166.568.007\$200, com 193.631 .746 pés de café, produzindo, representando na safra 1927/8 a produção de 1.656.473 sacas de café e 26.029.930 pés de cafés novos. A expectativa era do aumento desses números nos três anos seguintes, já que os produtores não cadastrados encontrariam dificuldades na venda e exportação de seu café, pela falta de guias do Instituto (IFEA, 1926-7:277-78).

No entanto o esquema de fixação de cotas mensais para exportação foi alvo de

\footnotetext{
${ }^{17}$ A divergência com as ferrovias envolvia certamente a questão do tráfego de mercadorias, no caso o café, que se constituía na base das receitas e da rentabilidade das estradas de ferro em geral. Os períodos das safras eram ocasiões propícias para elevar as receitas, compensando os períodos de baixa no volume dos transportes.
} 
inúmeros protestos, levando o IFEA a rever tal procedimento. Implicitamente se reconheciam as dificuldades operacionais de adaptação às novas regras pelas partes envolvidas: o instituto, lavradores e comerciantes. Outra crítica apontava o fato de que o esquema contrariava acordo firmado anteriormente entre os estados produtores, que definia quantidades totais de embarque, tendo como referência o que fora embarcado no mês anterior. Diante desse quadro, a direção do IFEA deliberou: a) por tornar sem efeito as guias de exportação expedidos pela instituição para as safras de 1926-7 e 1927-8; b) por reestabelecer o regime anterior de fixação prévia das cotas de embarque de café nas estações exportadoras. De acordo com o Convênio firmado em 28 de maio de 1927 entre os estados de São Paulo, Rio de Janeiro, Minas Gerais e Espírito Santo, o escoamento das sacas de café seria diário, tendo por base o total exportado no mês anterior, dividido por 25 dias úteis (IFEA, 1926-7:281).

A avaliação do Instituto sobre os últimos episódios tinha respaldo numa forma de pensamento crítico, que se consolidava na ocasião, acerca da capacidade reguladora dos preços pelo livre mercado. Reconhecia a importância do convênio entre os estados produtores, na medida em que (IFEA, 1926-7:286, grifos nossos):

Constitui-se, afinal, a "frente única", há tanto tempo reconhecida como indispensável para a obtenção dos resultados que a defesa do café poderia trazer à lavoura, agora inteiramente irmanada para a luta, ponderada, mas decisiva, contra os baixistas e especuladores. Regulamentou-se, por assim dizer, a lei econômica da oferta e da procura, impedindo as ofertas em demasia para que ao retraimento da procura não resultasse o aviltamento dos preços.

\section{O primeiro aniversário de instalação do Instituto}

A comemoração do primeiro aniversário de instalação da instituição foi uma ocasião propícia para um balanço do trabalho realizado até aquele momento. $\mathrm{Na}$ sessão comemorativa, em $1^{\circ}$ de outubro de 1927, que contou com a presença do governador do Estado, Feliciano Sodré, o gerente Francisco Correa Figueiredo sumariou algumas das conquistas obtidas pela instituição, tendo sido ainda sugerida a criação de uma "Caixa Beneficente dos Funcionários do Instituto".

De início foi ressaltada a gradativa aceitação do órgão junto ao meio social fluminense. Até mesmo a imprensa, principal reduto dos opositores, inicialmente hostil, já o via com "acentuada simpatia". Outro indicador de reconhecimento era a quantidade de ofícios, processos e circulares registrados pela burocracia institucional até aquela data. $\mathrm{O}$ número de 1185 lavradores inscritos até aquele instante também era um feito celebrado, tanto 
por serem eles os eleitores do diretor representante da lavoura, quanto por ser um indicativo da aceitação dos princípios e da forma de participação nas decisões do órgão. Como vimos, desde sua criação, essa modalidade de associação era o diferencial em relação às organizações classistas pré-existentes, conforme defendia Oliveira Vianna.

Continuando em sua prestação de contas, a gerência do Instituo registrou que, em seus poucos meses de trabalho, o Departamento de Fiscalização já cadastrara 9023 propriedades cafeeiras pertencentes a 8550 proprietários. Tratava-se de um registro importante que, quando concluído, permitiria à instituição agir com rigor e justiça no controle das saídas do café (IFEA, 1926-7:196).

A maior tarefa do órgão, no entanto, continuava sendo seu envolvimento com o programa de regulamentação do transporte e defesa dos preços do café, exemplificado no rigoroso cumprimento das cláusulas dos convênios celebrados com os demais estados cafeicultores, desde sua criação. Nas palavras do gerente Francisco de Figueiredo (IFEA, 1926-7:195-6):

\begin{abstract}
Aos compromissos assumidos com os demais estados cafeeiros, temos guardado o mais absoluto respeito, não excedendo uma só vez sequer, até agora, as cotas gerais de exportação que nos têm sido atribuídas em cada período, muito embora sinceramente nos custe a todo instante recusar aquiescência à medida de exceção solicitada em casos verdadeiramente excepcionais.
\end{abstract}

Por fim, era feita uma menção sobre os fundos de recurso para manutenção da instituição e realização de seus objetivos. A maior parte da renda, em torno de $78 \%$, era proveniente da taxa de mil réis ouro sobre o café exportado. Entre os meses de setembro de 1926 e 1927 o Instituto arrecadou a importância de 3.970:551\$200 (3970 contos, 551 mil e 200 réis). Em relação à taxa de 300 réis ouro cobrada sobre o açúcar, o valor arrecadado foi de 1.293:299\$500 (mil duzentos e noventa e três contos, 299 mil e 500 réis). Às vésperas da data comemorativa, a quantia total depositada em diversos bancos era de 3.678:904\$831 (3687 contos, 904 mil, 831 réis) (IFEA, 1927:197).

Nos anos seguintes, a regulamentação das entradas do café nos vários mercados se manteve como principal instrumento da defesa do produto, para a qual o Instituto direcionou suas ações. Em setembro de 1928 foi realizado o terceiro convênio entre os estados produtores, que referendou essa diretriz, baseando-se nas necessidades de consumo dos mercados. Outros temas, tais como o financiamento da produção, a uniformização de taxas e impostos e a propaganda no exterior, também foram discutidos no encontro, que reuniu os representantes dos estados de São Paulo, Minas Gerais, Rio de Janeiro, Espírito Santo, 
Paraná, Pernambuco, Bahia e Goiás.

A ampliação do número de participantes no encontro para renovação do convênio cafeeiro refletia, por um lado, a difusão da cultura do produto em outras regiões do país, sem dúvida resultado da política de defesa permanente e, por outro, a consecução de uma ação articulada de cooperação entre os estados produtores, fundamental para que o programa alcançasse seus objetivos. Na avaliação do IFEA, a partir de setembro de 1927, havia se constituído uma "frente única" dos estados cafeeiros,

(...) indispensável para a obtenção dos resultados que a defesa do café poderia trazer à lavoura, agora inteiramente irmanada para a luta, ponderada, mas decisiva, contra os baixistas e especuladores. Regulamentase, por assim dizer, a lei econômica da oferta e da procura, impedindo-se as ofertas em demasia para que do retraimento da procura não resultasse o aviltamento dos preços. (IFEA, 1926-7:286; grifos nossos)

Na safra de 1927-1928, a exportação geral do café fluminense foi de 1.123 .633 sacas, exportada pelos portos do Rio de Janeiro, a maior parte (98\%), e de Niterói. Na safra seguinte, de julho de 1928 a junho de 1929, a exportação foi de 794.424 sacas, mantendo praticamente a mesma proporção da anterior nos referidos portos.

Uma vez que os armazéns reguladores do Rio de Janeiro, com capacidade de armazenamento superior a 300 mil sacas, já se encontravam sob a direção do Instituto, o órgão voltava-se para a busca de soluções para a questão do crédito aos produtores.

Visando atender às solicitações de adiantamentos sobre os cafés armazenados em seus reguladores, o IFEA efetuou contratos de penhora com juros de 7 a $10 \%$ ao ano, despendendo, até agosto de 1929, um total de 3.890:190\$700 (três mil oitocentos e noventa contos, cento e noventa mil e setecentos réis) nessas operações.

Outra iniciativa foi a construção, em Niterói, de um armazém regulador com capacidade superior a 250 mil sacas, no valor de 1.402:669\$000 (Andrada. Mensagem, 1929:163-166). Para tanto foi cedida pelo governo fluminense uma área situada entre as ruas Gal. Castrioto e Galvão, nos bairros de Neves e Barreto, por sua proximidade da Estrada de Ferro Leopoldina e da zona portuária no centro de Niterói. As obras foram iniciadas em julho de 1929, com previsão para conclusão no início de 1930, tendo sido, porém, adiadas para maio do mesmo ano (Ver foto em Anexo do armazém em construção).

O quarto convênio, celebrado entre os estados de São Paulo, Minas Gerais, Rio de Janeiro, Paraná, Goiás, Bahia, Espírito Santo e Pernambuco em setembro de 1929, considerou que a defesa do café não necessitava de mudança em relação à maneira como vinha sendo 
levada. As cláusulas do Convênio anterior foram prorrogadas por mais um ano, exceto quanto à quinta, que tratava das cotas de cada Estado. A revisão desse item ficou a cargo do estudo de uma comissão formada por representantes dos estados envolvidos, cujos resultados seriam remetidos ao governo federal, com um pedido para regulamentação da lei $\mathrm{n}^{\circ} 5378$ de 14 de dezembro de 1927 (IFEA-RJ, 1929:117-121).

Com o advento da crise econômica mundial do final de 1929, os estados cafeicultores pareciam dispor dos instrumentos necessários para enfrentá-la, talvez desconhecendo sua gravidade e profundidade. Embora fosse constatada a situação de superprodução cafeeira, a direção do IFEA acreditava que a propaganda e a ampliação do consumo externo poderiam alterar de forma significativa aquele quadro. $\mathrm{O}$ trecho a seguir registra essa expectativa de se ampliar a demanda externa para equilibrar a oferta (IFEA, 1929:190):

Contudo, é preciso ter em conta que as possibilidades de aumento do consumo de café são quase ilimitadas, porquanto praticamente a maior parte da humanidade desconhece o seu uso, sendo bastante conseguir que um só país, digamos a Inglaterra, o consumisse em proporção semelhante aos Estados Unidos, ou aos países escandinavos para sobrevir uma fome mundial de café.

A queda acentuada do preço do café no mercado mundial atingiu as exportações brasileiras, cujo valor caiu cerca de 25\% entre 1928 e 1931 (Abreu, 1999:75-77). O agravamento da crise e a depressão que atingiu a economia mundial ao longo da década de 1930 sepultaram as expectativas dos valorizadores de se equilibrar a oferta do café a partir de um aumento da procura. $\mathrm{O}$ novo quadro em que mergulhara a economia capitalista mundial estava a exigir novas formas para enfrentá-lo.

No cenário nacional a crise da cafeicultura articulou-se com a crise política institucional que culminou, em outubro de 1930, com o fim da República oligárquica e o advento da Era Vargas. A mudança no quadro político nacional resultou, entre tantas, no gradativo enfraquecimento dos poderes dos executivos estaduais em detrimento do federal. $\mathrm{Na}$ reconfiguração dos grupos no poder e do aparato estatal, a nova ordem já podia dispor de uma série de dispositivos, econômicos e jurídicos, que seriam acionados e aperfeiçoados na tentativa de superar as dificuldades do setor agroexportador. Em relação ao café, já havia algumas diretrizes que seriam absorvidas e integradas ao aparato jurídico e institucional criado na década de 1930. Proteger o café de uma queda acentuada nos preços, através da compra e retirada do mercado de estoque excedentes, financiar essas operações com recursos internos, assim como atribuir a execução destas medidas a órgãos públicos, foram alguns dos 
instrumentos herdados da "velha ordem", que fariam parte da onda renovadora do país a partir de 1930.

\section{Considerações finais}

Esse artigo limitou-se a apresentar a conjuntura econômica e política da década de 1920 que presidiu à criação do Instituto de Fomento e Economia Agrícola do Rio de Janeiro, assim como os principais procedimentos adotados pelo mesmo para implementar a política de defesa permanente do café fluminense entre 1926 e 1927.

Conquanto as atribuições do Instituto fossem mais amplas, este artigo optou por apresentar um recorte de sua atuação em relação ao café, principal produto de exportação do país e do estado, num conjuntura de crise econômica e de transformação política. A ocasião exigiu uma postura mais incisiva, organizada e duradoura por parte dos órgãos públicos em defesa dos preços do café. Foi, portanto, um momento de estruturação das bases dessa ação, que incorporava a responsabilidade dos estados produtores, e que perduraria até a retomada do controle da política cafeeira pelo governo federal no início da década de 1930.

Entretanto, pode-se afirmar que os fundamentos, institucionais e financeiros, para um programa defensivo de escopo nacional, já haviam sido lançados desde meados de 1920. Os principais pilares desse programa eram: os Institutos e Serviços de Defesa do Café estaduais, com propósito de regular a saída do produto e controlar sua oferta; as fontes de recursos para financiar essas ações defensivas, assim como o estímulo para organização e participação dos agricultores nesses novos órgãos.

Uma análise histórica sobre a instituição requer, no entanto, um estudo mais aprofundado que englobe o exame das ações relativas aos demais produtos da agricultura fluminense, assim como de sua organização interna, seu quadro funcional, sua relação com outras instituições surgidas no período e com o meio sociopolítico fluminense e nacional. Esta seria, no entanto, outra tarefa.

Sob a perspectiva aqui apresentada, o estudo considera a atuação do IFEA/RJ como uma contribuição exemplar na definição de um estilo de política voltada para a defesa do setor cafeeiro por parte do setor público, anterior ao advento do intervencionismo estatal da década de 1930. 


\section{Referências Bibliográficas}

ABREU, Marcelo de Paiva. O Brasil e a economia mundial. Rio de Janeiro: Civilização Brasileira, 1999.

ANDRADA, Antonio Carlos Ribeiro de. Mensagem apresentada pelo presidente do Estado de Minas Gerais ao Congresso Mineiro e lida na abertura da $3^{a}$ sessão ordinária da $10^{a}$ legislatura. Belo Horizonte: Imprensa Oficial de Minas Gerais, 1929.

BARROS DE CASTRO, Antônio. 7 Ensaios sobre a economia brasileira. Rio de Janeiro: Forense, 1977. Vol. 2.

BRASIL. Mensagem apresentada ao Congresso Nacional na abertura da segunda sessão da $11^{a}$ legislatura pelo Presidente da República Epitácio Pessoa. Rio de Janeiro: Imprensa Nacional, 1922.

. Departamento Nacional do Café. O Café no segundo centenário de sua introdução no Brasil. Rio de Janeiro: Edição do Departamento Nacional do Café, 1934. 2 vls.

DE LORENZO, Helena C.; COSTA, Wilma P. da (orgs.). A década de 1920 e a origem do Brasil moderno. São Paulo: UNESP, 1997. pp. 217-233.

DELFIM NETO, Antônio. O problema do café no Brasil. São Paulo: IPE/USP, 1981.

FERREIRA, Marieta de Moraes. Em busca da idade de ouro: as elites políticas fluminenses na Primeira República (1889-1930). Rio de Janeiro: Editora UFRJ; Edições Tempo Brasileiro, 1994.

. A República na velha província: oligarquia e crise no Estado do Rio de Janeiro (18891930). Rio de Janeiro: CPDOC/FGV - Rio Fundo, 1989.

e LAMARÃO, Sergio T. N. Fontes para o estudo da História do Estado do Rio de Janeiro na Primeira República. BIB. Rio de Janeiro, n. 20, pp. 23-40, 2º semestre de 1985.

FURTADO, Celso. Formação econômica do Brasil. 11. ed. São Paulo: Cia. Editora Nacional, 1972.

HOLlOWAY, Thomas H. Vida e morte do convênio de Taubaté: a primeira valorização do café. Rio de Janeiro: Paz e Terra, 1978.

INSTITUTO DE FOMENTO E ECONOMIA AGRÍCOLA DO ESTADO DO RIO DE JANEIRO. Relatório apresentado à Diretoria do Instituto por intermédio do respectivo presidente Dr. Antônio Joaquim Mello, secretário de Estado das Finanças, pelo gerente, bacharel Francisco Corrêa de Figueiredo. 1926 - 1927. IFEA: Niterói, 1928. 
(Publicação n ${ }^{\circ}$ 9)

Idem. 1928. IFEA: Niterói, 1929. (Publicação n 10)

Idem. 1929. IFEA: Niterói, 1930. (Publicação nº 11)

. Leis, Regulamento e Estatutos. Rio de Janeiro: Typ. do Jornal do Comercio, 1926.

. Regulamento e Estatutos. IFEA: Niterói, 1929.

O Regimen Torrens no Estado do Rio de Janeiro. IFEA: Niterói, 1927.

MELLO, Joaquim de. Evolução da cultura cafeeira no Estado do Rio. Fastígio, decadência e ressurgimento do café na terra fluminense - De Resende, seu "habitat" primitivo a Itaperuna, maior município produtor do Brasil. In: BRASIL. Depto. Nacional do Café. $O$ Café no segundo centenário de sua introdução no Brasil. Rio de Janeiro: DNC, 1934. pp. 413-423. Vol. 1

MELO, Hildete Pereira de. O Café e a economia do Rio de Janeiro (1888-1920). Tese de doutorado. Rio de Janeiro: IE/UFRJ, 1993.

MENDONÇA, Sônia Regina de. O Convênio de Taubaté e a agricultura fluminense. Revista Brasileira de Gestão e Desenvolvimento Regional. Vol. 4, n. 3, Taubaté, SP, 2008.

MOTTA, Márcia (org.). Dicionário da terra. Rio de Janeiro: Civilização Brasileira, 2005.

PERISSINOTTO, Renato M. Estado e capital cafeeiro em São Paulo (1889-1030). São Paulo: Fapesp; Campinas, SP: Unicamp, 1999. Tomos I e II.

Classes dominantes e hegemonia na República Velha. Campinas, SP: Editora Unicamp, 1994.

RANGEL, Sylvio Ferreira. O Café no Estado do Rio de Janeiro. Sua origem e influência na na vida econômica e social da terra fluminense. In: DEPTO. NACIONAL DO CAFÉ. $O$ Café no segundo centenário de sua introdução no Brasil. Rio de Janeiro: DNC, 1934. pp. 161-7. Vol. 1.

SANCHES, Almir Teubl. A questão de terras no início da República: o Registro Torrens e sua (in)aplicação. Dissertação de mestrado. São Paulo: Faculdade de Direito/USP, 2008.

TAUNAY Affonso de E. História do café no Brasil. Rio de Janeiro: Departamento Nacional do Café, 1941. Vol. 12, tomo II.

Pequena história do café no Brasil (1727-1927). Rio de Janeiro: Departamento 
Nacional do Café, 1945.

TOPIK, Steven. A presença do estado na economia política do Brasil de 1889 a 1930. Rio de Janeiro: Record, 1987.

VIANNA, F. J. Oliveira e LEITE, Eurico Teixeira. O Regimen Torrens no Estado do Rio de Janeiro. Nictheroy: Instituto de Fomento e Economia Agrícola do Rio de Janeiro, 1927.

VIDAL, Armando (org.). Defesa do café no Brasil. Coletânea de documentos oficiais. $1^{\circ}$ vol. Rio de Janeiro: Departamento Nacional do Café, 1935. 


\section{ANEXOS}

ANEXO 1: Municípios do Estado do Rio de Janeiro que exportaram café em 1928, segundo as zonas produtoras

(Em negrito os municípios que exportaram mais de 50 mil sacas)

\begin{tabular}{|c|c|c|}
\hline ZONA PRODUTORA & MUNICIPIOS & $\begin{array}{l}\text { SACAS EXPORTADAS } \\
(60 \mathrm{Kg})\end{array}$ \\
\hline $\begin{array}{l}\text { Zona Serrana do Vale Sul } \\
\text { do Paraíba }\end{array}$ & $\begin{array}{l}\text { Barra Mansa } \\
\text { Barra do Piraí } \\
\text { Paraíba do Sul } \\
\text { Petrópolis } \\
\text { Piraí } \\
\text { Resende } \\
\text { Santa Teresa } \\
\text { Sapucaia } \\
\text { Valença } \\
\text { Vassouras }\end{array}$ & $\begin{array}{r}12.751 \\
8.086 \\
11.398 \\
8.793 \\
185 \\
8.562 \\
8.577 \\
2.322 \\
34.180 \\
8.727\end{array}$ \\
\hline Zona Serrana do Centro & $\begin{array}{l}\text { Bom Jardim } \\
\text { Cantagalo } \\
\text { Carmo } \\
\text { Duas Barras } \\
\text { Macaé } \\
\text { Nova Friburgo } \\
\text { Sta. Maria Madalena } \\
\text { São Francisco de Paula } \\
\text { Sumidouro }\end{array}$ & $\begin{array}{r}\mathbf{6 6 . 7 1 4} \\
37.992 \\
8.933 \\
10.265 \\
\mathbf{5 2 . 1 3 5} \\
11.603 \\
23.961 \\
21.565 \\
9.617\end{array}$ \\
\hline $\begin{array}{l}\text { Zona Norte Fluminense ou } \\
\text { Vale Norte do Paraíba }\end{array}$ & $\begin{array}{l}\text { Cambuci } \\
\text { Campos } \\
\text { Itaocara } \\
\text { Itaperuna } \\
\text { Sto. Antônio de Pádua } \\
\text { São Fidélis } \\
\text { São João da Barra }\end{array}$ & $\begin{array}{rr} & 22.866 \\
& 40.146 \\
& 14.000 \\
& \mathbf{2 9 9 . 8 6 7} \\
& \mathbf{1 5 8 . 1 4 1} \\
& 39.323 \\
& 1.951 \\
\mathbf{5 7 6 . 2 9 4} & \\
(61,2 \%) & \\
\end{array}$ \\
\hline $\begin{array}{l}\text { Zona Litorânea ou da } \\
\text { Baixada }\end{array}$ & $\begin{array}{l}\text { Barra de São João } \\
\text { Capivari } \\
\text { Niterói } \\
\text { Rio Bonito } \\
\text { Sant' Anna de Japuiba } \\
\text { São Gonçalo } \\
\text { Saquarema }\end{array}$ & $\begin{array}{r}8.956 \\
7.268 \\
1.768 \\
726 \\
159 \\
25 \\
1\end{array}$ \\
\hline TOTAL & & $\begin{array}{c}\mathbf{9 4 1 . 5 6 3} \\
(100 \%)\end{array}$ \\
\hline
\end{tabular}

Fonte: A partir de dados apresentados por: IFEA-RJ. Relatório (...). 1928. Anexo nº 7. 
ANEXO 2: Foto do armazém regulador do IFEA/RJ em Niterói (em construção) - 1929

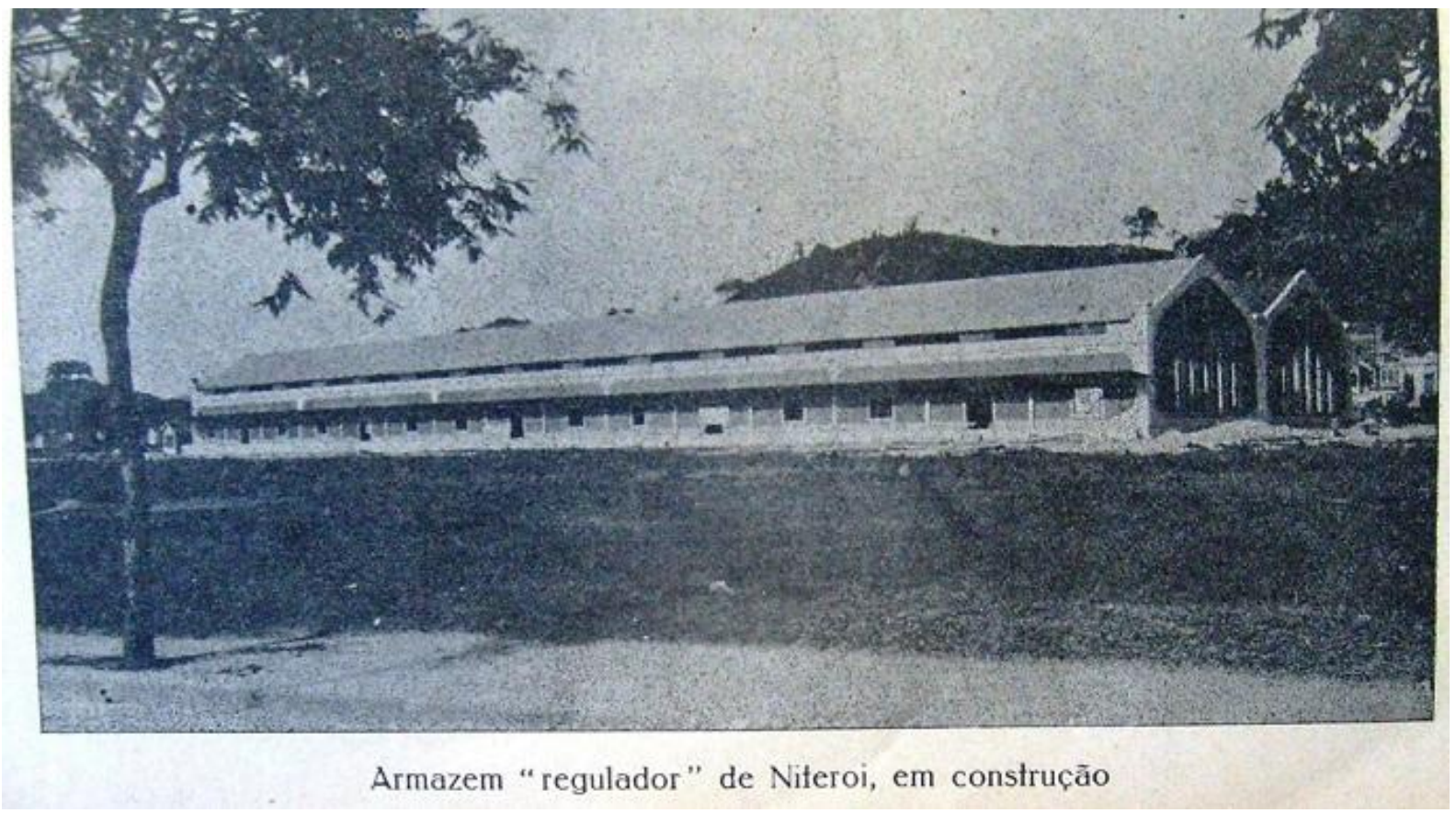

Fonte: IFEA; Relatório..., 1929. Foto entre pp. 166-167. 
ANEXO 3: Foto da nova sede do IFEA/RJ concluída em setembro de 1929 na Avenida Feliciano Sodré em Niterói-RJ

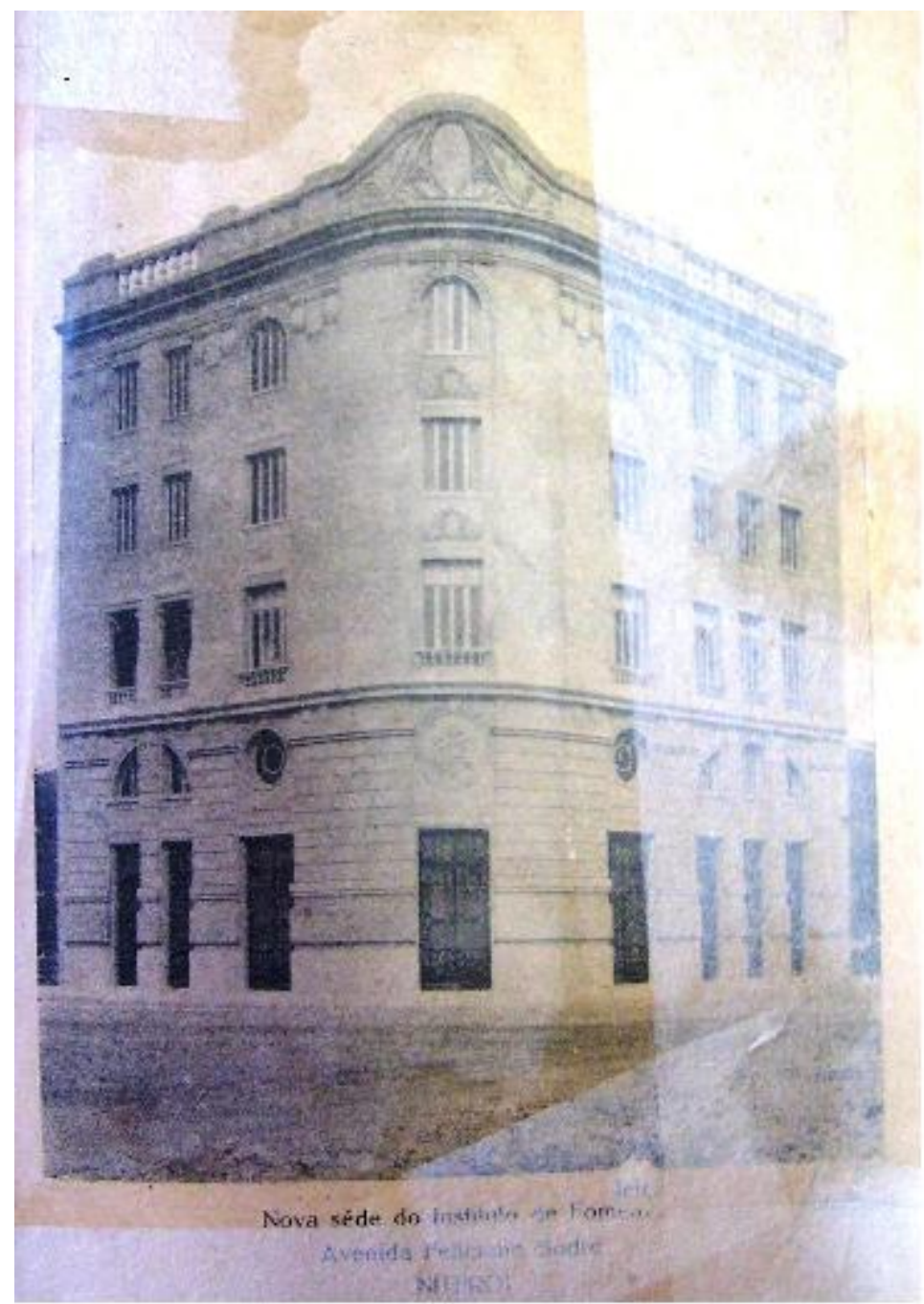

Fonte: IFEA-RJ. Relatório; 1929. Foto na pag. inicial do relatório. 